\title{
海洋天然气水合物开采技术与装备发展研究
}

\author{
付强 $^{1}$, 王国荣 ${ }^{2}$, 周守为 ${ }^{1}$, 钟林 ${ }^{2}$, 王雷振 ${ }^{2}$ \\ (1. 中海油研究总院有限责任公司, 北京 100028; 2. 西南石油大学机电工程学院, 成都 610500)
}

\begin{abstract}
摘要: 天然气水合物尤其是海洋天然气水合物是有望替代传统化石能源的一种新型清洁非常规能源, 全球储量丰富, 目前对 其开采仍处于研究阶段, 商业化、规模化开采面临诸多技术与装备挑战。本文针对现有水合物开采方法, 围绕日本和我国的 海洋天然气试采工程案例, 对降压和固态流化法两种试采模式涉及的关键技术和工艺进行了分析; 综合国内外相关技术与装 备的发展现状, 提出了适合我国储层与装备技术的海洋天然气水合物开采的发展思路及对策建议。研究发现, 在以深海采矿 车、疏松浅表层双梯度钻井技术等为代表, 用于水合物 - 油气 - 海底金属矿开采的通用关键技术装备领域, 我国的整体水平 落后于国外；在以防砂技术装备、浅层水合物开采的预斜导向钻进技术、“三气合采” 技术装备等为代表的专用关键技术装 备领域, 我国综合水平与国际先进水平相当, 但仍然距商业化开采技术装备需求较远。面向 2035 年, 我国海洋天然气水合 物开采技术与装备发展的战略目标为进入全面领跑阶段, 建立商业化开发的工程装备体系。研究建议, 从国家层面制定海洋 天然气水合物开发技术与装备研发计划, 推动水合物的商业化开发进程, 开展海洋非成岩水合物开采专用和通用技术装备的 研发及应用。
\end{abstract}

关键词：海洋天然气水合物；开采模式；通用技术装备；专用技术装备

中图分类号: TE1 文献标识码: A

\section{Development of Marine Natural Gas Hydrate Mining Technology and Equipment}

\author{
Fu Qiang ${ }^{1}$, Wang Guorong ${ }^{2}$, Zhou Shouwei ${ }^{1}$, Zhong Lin $^{2}$, Wang Leizhen ${ }^{2}$ \\ (1. CNOOC Research Institute Co., Ltd., Beijing 100028, China; 2. School of Mechanical Engineering, Southwest Petroleum \\ University, Chengdu 610500, China)
}

\begin{abstract}
Natural gas hydrate, especially marine natural gas hydrate, is a new clean unconventional energy which is expected to replace the traditional fossil energies. The global reserve for the natural gas hydrate is rich; but its exploitation is still in the research stage, and the commercial and large-scale exploitation faces many challenges regarding technology and equipment. Aimed at the existing hydrate exploitation methods, this study analyzes the key technologies and processes involved in two trial production modes (i.e., depressurization and solid-state fluidization) that were adopted in the pilot production projects of offshore natural gas in Japan and China, summarizes the development status of relevant technology and equipment in China and abroad, and proposes some development suggestions for marine gas hydrate exploitation suitable for the reservoir and equipment technology in China. We found that China lags behind other countries in the fields of general key technologies and equipment for hydrate, oil gas, and subsea metal mining, represented by deep-sea mining vehicles and dual-gradient drilling technology for the loose shallow layer. In the field of special key technologies and equipment, represented by sand control technology and equipment, pre-inclined directional drilling technology for
\end{abstract}

收稿日期 : 2020-09-27; 修回日期 : 2020-11-09

通讯作者: 王国荣, 西南石油大学机电工程学院教授, 研究方向为天然气水合物开采工艺技术及装备; E-mail: swpi2002@163.com 资助项目：中国工程院咨询项目 “海洋装备发展战略研究” (2020-ZD-02); 中国工程院咨询项目 “面向 2035 海洋能源开发及核心技术战略 研究” (2020-ZD-13)

本刊网址：www.engineering.org.cn/ch/journal/sscae 
shallow hydrate mining, and combined production of hydrate, free gas, and conventional natural gas, China's comprehensive level is equivalent to the international advanced level, but it still cannot satisfy the requirements for commercial mining. The development of exploitation technologies and equipment for marine natural gas hydrates in China is expected to enter a leading stage in 2035, and an engineering equipment system for commercial development is expected to be established by then. To this end, we suggest that a research and development plan for marine natural gas hydrate exploitation technology and equipment should be formulated at the national level, so as to promote the commercial development of hydrates, and the research and application of special and general technologies and equipment for offshore non-diagenetic hydrate exploitation should be accelerated.

Keywords: marine natural gas hydrate; exploitation mode; general technology and equipment; special technology and equipment

\section{一、前言}

天然气水合物是由天然气和水在低温与高压情 况下生成的固态笼型化合物 [1], 作为一种高能量 密度资源, 地球蕴藏资源总量巨大 [2]。全球天然 气水合物资源包含的 $\mathrm{CH}_{4}$ 气体总量约为 $3 \times 10^{15} \mathrm{~m}^{3}$, 主要存在于海底和陆地永冻土区域, 其中海洋天然 气水合物约占天然气水合物总量的 $95 \%$ 以上 [3]。 因此, 天然气水合物尤其是海洋天然气水合物通常 被视为能够替代传统化石能源的新型清洁非常规能 源 [4]。根据水合物分解后地层是否保持完整骨架 结构, 天然气水合物可分为成岩和非成岩两种类型; 除少数砂岩型及砂岩裂隙型水合物属于成岩型, 占 水合物总量绝大多数的细粒裂隙型和分散型水合物 均属于非成岩型水合物 [5]。其中，分散型的天然 气水合物资源存在于海底细颗粒沉积物中, 约占水 合物资源总量的 $90 \%$ ，具有饱和度低 $(<10 \%$ 的孔 隙体积)、胶结性弱、渗透性差的特点, 开采此类 水合物存在技术难度高、经济性差、风险大等问题。 我国南海天然气水合物多属于此种类型, 亟需在开 采工艺、技术和装备上取得突破, 支撑南海水合物 的商业化开采进程。

目前, 天然气水合物开采方法主要有注热法、 注化学制剂法、 $\mathrm{CO}_{2}$ 置换法、降压法、固态流化 法 [6], 前 4 种为传统开采方法, 属于原位分解出 天然气的方法, 其原理如图 1 所示。具体来看, 注 热法主要通过向水合物层注入热流体，打破水合物 相平衡的条件, 促使水合物分解出天然气; 注化学 剂法通过向地下水合物层注入化学剂改变水合物固 有相平衡, 进而使水合物在原有温度压力条件下分 解; $\mathrm{CO}_{2}$ 置换法基于 $\mathrm{CO}_{2}$ 分子更易于与水结合的特 点, 通过向地层注入 $\mathrm{CO}_{2}$ 将天然气置换出来; 降 压法通过降低水合物储层压力以打破水合物相平 衡状态，促使水合物分解; 固态流化法是在原位
保证流化水合物为固态，待水合物进入密闭空间 后再促进其分解。注热法和注化学剂法经济性较 差 $[7,8]$, 目前对这两种方法的研究相对较少 [9]。 $\mathrm{CO}_{2}$ 置换法具有降低地质灾害风险、封存 $\mathrm{CO}_{2}$ 以 缓解温室效应的优点 [10], 但置换速率和置换效 率较低 [11] 制约了方法应用。降压法无需连续激 发, 被认为是极具发展潜力且经济的天然气水合 物开采方法 [12], 但存在的问题是水合物二次生 成、开采效率低以及可能引发海底滑坡、井壁失 稳等地质工程灾害 [13]。与其他开采方法相比, 固 态流化法能降低水合物地下分解所引发的地质环 境风险, 但存在产量偏低、采后地层修复技术难 度大等问题 [14]。目前, 降压法和固态流化法已成 功用于海洋天然气水合物试采工程, 标志着开采 技术的重大进步。但也应清楚认识到, 试采的水 合物产量还很低, 相较商业化开采的差距仍然很 大，开采过程中的潜在地质、装备、环境风险仍 未从根本上消除。因此, 有必要对水合物开采技 术和装备发展现状进行分析, 剖析制约水合物发 展的技术瓶颈。

本文重点针对海洋天然气水合物降压和固态流 化两种开采模式, 从水合物开采专用技术装备、水 合物 - 海洋油气 - 海底矿产通用技术装备两个角度 分析发展现状及存在问题, 提出领域发展建议, 为 水合物开采技术与装备发展路线研究提供参考。

\section{二、海洋天然气水合物试采工程案例分析}

\section{（一）日本 Nankai 海槽天然气水合物降压法开采}

目前, 全球已开展了 5 次海洋天然气水合物试 采作业, 有效推动了相关开采技术的发展。首次海 洋天然气水合物试采作业由日本于 2013 年 3 月在 Nankai 海槽开展, 采用流体抽取的方式对水合物矿 藏进行降压开采, 利用电潜洜将流体抽出, 降低地 


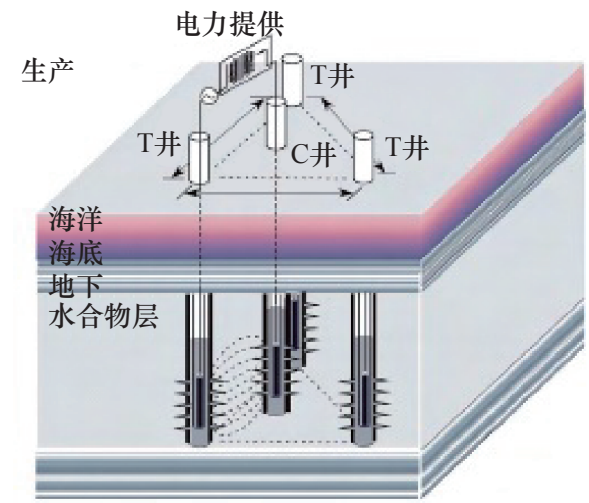

(a) 注热法

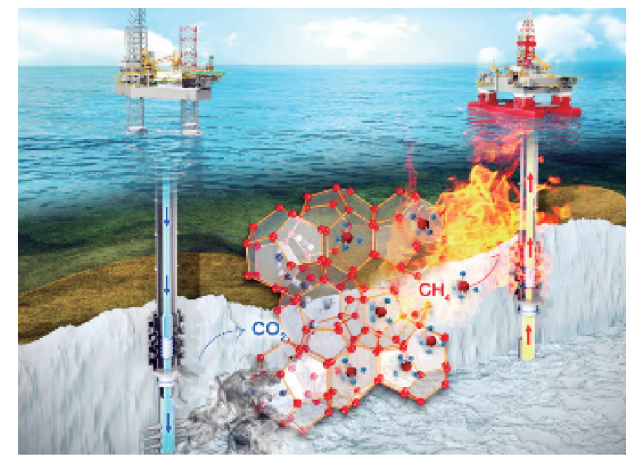

(c) $\mathrm{CO}_{2}$ 置换法

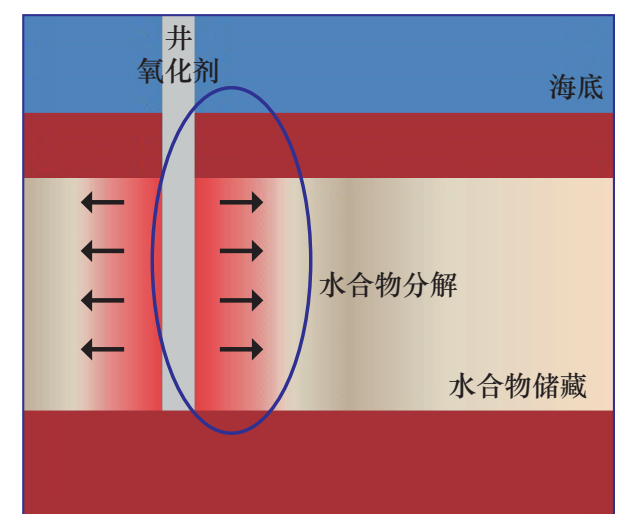

(b) 注化学试剂法

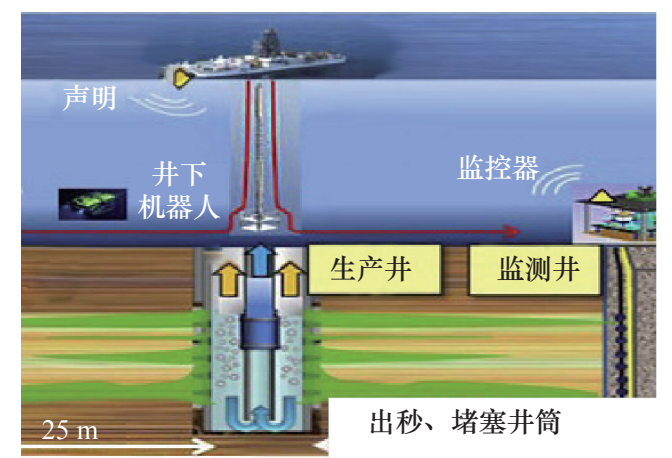

(d) 降压法

图 1 水合物传统开采方法的工艺原理示意图

层压力, 将天然气水合物分解采出; 但因井底出砂 问题而被迫停止试采作业。经过 $6 \mathrm{~d}$ 试采作业, 累 计开采的天然气为 $1.2 \times 10^{5} \mathrm{~m}^{3}$ [15]。2017 年, 日本 在相同海域进行了第二次试采, 同样由于井底严重 出砂问题而被迫切换至第二口开采井 [16]。日本两 次试采初步验证了降压开采海洋天然气水合物的技 术可行性, 但井底出砂问题亟待解决。

\section{（二）中国南海神狐海域天然气水合物降压法试采}

2017 年 5-7 月, 我国采用降压法在南海神狐 海域实施了海洋天然气水合物试采作业, 针对试采 储层沉积物为细粒沉积物、渗透率低的特点, 采用 水力割缝方法对储层进行改造, 有效提高了试采产 量 [17]。中国地质调查局于 2019 年 10 月一 2020 年 4 月在南海水深 $1225 \mathrm{~m}$ 的神狐海域进行了第二次 天然气水合物降压试采 [18]。两次试采攻克了钻井 井口稳定性、水平井定向钻进、储层增产改造与防 砂、精准降压等一系列深水浅软地层水平井技术 难题, 实现连续产天然气 $30 \mathrm{~d}$, 共计产出天然气 约 $8.614 \times 10^{5} \mathrm{~m}^{3}$, 日均产天然气为 $2.87 \times 10^{4} \mathrm{~m}^{3}$, 标
志着我国海洋天然气水合物开采技术达到国际领先 水平。也应清醒认识到, 这仅是短期试采的成功, 其产量和开采时长远未达到商业化开采级别, 长期 开采的潜在地质环境风险问题仍未从根本上解决, 短期试采所使用的开采技术和装备能否经受长期商 业化开采的考验, 仍需进一步验证。

\section{（三）中国南海固态流化法试采}

2017 年 5 月, 中国海洋石油集团有限公司在南 海北部荔湾 3 站位依托 “海洋石油 708 ” 深水工程 勘察船, 利用完全自主研制技术、工艺和装备, 在 水深为 $1310 \mathrm{~m}$ 、水合物矿体埋深为 $117 \sim 196 \mathrm{~m}$ 处, 成功实施了全球首次海洋浅层非成岩天然气水合 物固态流化试采作业 [5]。南海固态流化法的试 采工艺流程如图 2 所示, 采掘过程中使用喷嘴射 流的方法破碎井眼周围水合物矿体以实现水合物 开采, 经过约 $2 \mathrm{~h}$ 的射流采掘过程, 产出天然气 约 $101 \mathrm{~m}^{3}$, 基本达到试采目标 [5]。本次作业在技 术层面初步验证了固态流化法开采海洋天然气水 合物工艺的可行性, 但固态流化法的产量还较低, 
存在钻井液漏失、高浓度矿浆输送、采空区地层 修复、水合物井筒应力累积有序释放调控等技术 难题 [19 21]。

结合海洋天然气水合物试采案例、试采过程相 关信息和典型技术装备可知（见表 1), 海洋天然气 水合物试采主要采用传统技术装备, 缺乏水合物规 模化开发的专用技术及配套装备。

\section{三、国内外海洋天然气水合物开采技术与装 备发展现状}

根据适用性的不同可将水合物开采技术装备分 为通用关键技术装备和专用技术装备：前者指不仅 适用于海洋天然气水合物开采行业, 还可以在海洋 油气或深海采矿等其他行业应用的技术装备; 后者 指仅适用于海洋天然气水合物开采的技术装备。

\section{（一）通用技术装备}

1. 深海采矿车

海底采矿车既是海底表层天然气水合物固 态流化开采技术中的关键装备, 又是海底矿产资 源开采技术中的关键装备。英国专业机械开发公 司 (SMD) 针对 Nautilus 采矿船项目开发了作业水 深达 $1700 \mathrm{~m}$ 、用于挖掘、粉碎及收集的 3 种大型装 备。长沙矿山研究院有限责任公司研制了作业水深 达 $1000 \mathrm{~m}$ 的采矿车, 但该采矿车属于实验性装备, 不具备挖掘破碎功能。目前, 上述两种装备已进行 了 $100 \mathrm{~m}$ 级水深的试验, 尚未在 $1000 \mathrm{~m}$ 级水深进
行作业; 均是针对海底矿物开采所研发的装备, 而 非针对海底表层水合物开采研发的装备。

\section{2. 疏松浅表层双梯度钻井技术}

我国提出了新型深水可控环空泥浆液面、海底 泥浆百举升和双层管双梯度的深水水合物安全钻进 新技术 [21], 但尚未达到工程应用水平。国外双梯 度钻井技术已经商业化并应用于深水油气钻井, 但 尚未应用于水合物开采; 技术相对成熟, 但对我 国实行技术封锁, 制约着我国深水浅层油气和水 合物的开采。

3. 高强度轻质柔性管

高强度轻质柔性管主要用于水合物和海洋油气

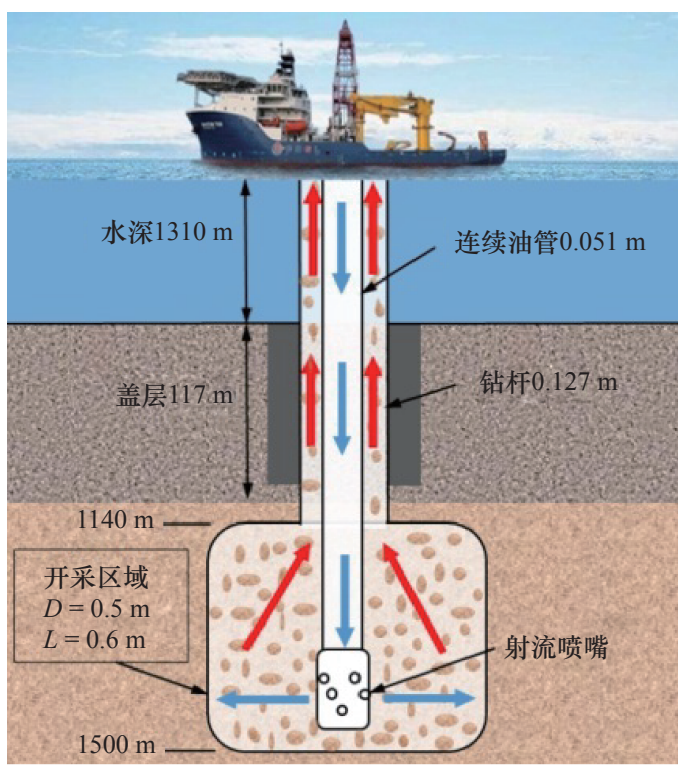

图 2 海洋天然气水合物固态流化试采工艺 [20] 注: $D$ 表示采掘腔体直径, $L$ 表示采掘腔体长度。

表 1 海洋天然气水合物试采的典型技术装备

\begin{tabular}{|c|c|c|c|c|}
\hline 采区域 & 储层特性 & 试采方式 & 典型装备 & 发展方向 \\
\hline 2013年和 2 & $\begin{array}{l}\text { 水深: } 1006 \mathrm{~m} \\
\text { 埋深: } 260 \sim 300 \mathrm{~m} \\
\text { 类型: 砂岩 }\end{array}$ & 条压法 & $\begin{array}{l}\text { “地球号”钻井船+隔 } \\
\text { +套管+防喷器+电潜泉 } \\
\text { +封隔器+举升分离器 }\end{array}$ & $\begin{array}{l}\text { 防砂系统、分离系统 } \\
\text { 井船减重; 梯度减压 } \\
\text { 系统需改进 }\end{array}$ \\
\hline F & $\begin{array}{l}\text { 水深: } 1266 \mathrm{~m} \\
\text { 埋深: } 203 \sim 277 \mathrm{~m} \\
\text { 类型: 泥质粉砂 }\end{array}$ & 压法 & $\begin{array}{l}\text { 半潜式钻井平台 ( “ } \\
\text { +隔水管+钻杆+连续 } \\
\text { +水力割缝工具+电 } \\
\text { 管+封隔器 }\end{array}$ & $\begin{array}{l}\text { 亟需低渗透地层改造; 举升防砂; } \\
\text { 密度窗口钻井, 水合物开采动 } \\
\text { 态监测 }\end{array}$ \\
\hline 狐i & $\begin{array}{l}\text { 水深: } 1310 \mathrm{~m} \\
\text { 埋深: } 117 \sim 192 \mathrm{~m} \\
\text { 类型: 泥质粉砂 }\end{array}$ & 固态流 & $\begin{array}{l}\text { 深水] } \\
+ \text { 钻杆 } \\
\text { 短接 }\end{array}$ & $\begin{array}{l}\text { 用采 } \\
\text { 管、 } \\
\text { 备 }\end{array}$ \\
\hline $\begin{array}{l}\text { 2020年中国南海 } \\
\text { 神弧海域第二轮 } \\
\text { 试采 }\end{array}$ & $\begin{array}{l}\text { 水深: } 1225 \mathrm{~m} \\
\text { 埋深: } 207 \sim 297 \mathrm{~m} \\
\text { 类型: 泥质粉砂 }\end{array}$ & 压法 & $\begin{array}{l}\text { 半潜式钻井平台 ( “蓝鲸 II 号” ) } \\
\text { +吸力针+钻杆+连续油管+防喷器 } \\
\text { +新型旁通预充填篮管+电潜㬌+ } \\
\text { 气液分离器+封隔器 }\end{array}$ & $\begin{array}{l}\text { 实现从“探索性试采” 向 “试验 } \\
\text { 性试采” 的重大跨越, 但水合物 } \\
\text { 规模化开发的技术装备仍未取得 } \\
\text { 突破 }\end{array}$ \\
\hline
\end{tabular}


开采领域。宝鸡石油机械有限责任公司具备生产连 续油管的能力, 但产品直径和长度等关键参数均与 国外存在较大差距。

\section{4. 海底矿浆举升㬌}

海底矿浆举升泵既可用于海洋水合物的开采, 还可用于海底矿产的开采。国内研制的矿浆洜可在 水深为 $1000 \mathrm{~m}$ 、矿浆最大颗粒粒径为 $20 \mathrm{~mm}$ 的工 况条件下实现排量为 $120 \mathrm{~m}^{3} / \mathrm{h}$ 的矿浆举升; 国外 矿浆洜适用水深、最大颗粒粒径、射流排量分别 为 $3500 \mathrm{~m} 、 50 \mathrm{~mm} 、 405 \mathrm{~m}^{3} / \mathrm{h}$ 。由此可见, 国内的 矿浆百与国外相比存在较大差距。

5. 海底 / 井下气 - 液 - 固多相分离器

目前, 井下分离器多为针对油气的气液分离器, 我国的水合物气 - 液 - 固多相井下分离器尚处于试 验研究阶段。国外已具备小处理量井下气 - 液 - 固 分离生产技术, 但仍无法达到水合物开采分离处理 量的要求。

综上, 国内的通用关键技术装备水平整体上落 后于国外, 仅有个别技术应用水平稍有领先; 国外 现有的装备技术水平相较水合物或海底金属矿商业 化开采要求仍然差距甚远。

\section{（二）专用关键技术装备}

\section{1. 防砂技术装备}

水合物储层多为非胶结的细粒沉积物, 水合物 开采过程中极易出现井下出砂问题。我国南海海域 水合物降压试采过程中采用了防砂篮管和新型旁通 预填充篮管防砂技术, 保障了试采过程顺利进行。 日本采用贝克休斯 GeoFORM 防砂工具, 在试采中 证明了井下膨胀防砂的有效性, 但因砂堵而导致试 采中断。综合而言, 目前国内防砂技术处于领先地 位, 但能否保障水合物长期商业化开采仍需进一步 评估。

2. 浅层水合物开采的预造斜导向钻进技术

不同于传统造斜导向的基础理论, 疏松浅表层 造斜导向对导向工具的强度、柔性、转弯半径、储 层适应性提出了更高要求, 亟需研制水合物开采 专用的预斜导向钻进技术及工具。国内方面的发 展进展为: 宏华集团发展了连续管超短半径导向 钻进技术, 可实现 $8^{\circ} \sim 9^{\circ} / 30 \mathrm{~m}$ 造斜技术指标; 奥 瑞拓能源科技股份有限公司提出了可适应松软地层
的弯螺杆造斜技术及装备 $\left(2^{\circ} \sim 4^{\circ} / 9.6 \mathrm{~m}\right)$; 中国 地质调查局采用吸力针预造斜导向钻进技术成功实 施海洋天然气水合物水平井开采。国外方面的发展 进展为: NeoDrill 技术公司提出基于吸力针的预造 斜导向钻井技术 $\left(90^{\circ} / 100 \sim 250 \mathrm{~m}\right)$, 美国斯伦贝 谢公司提出一种新型的钻头导向钻进技术及工具 $\left(16.7^{\circ} / 30 \mathrm{~m}\right)$ 。综合来看, 国内造斜技术水平与国 外相比尚存在一定差距, 特别是适应于松软地层的 预斜导向钻进技术。

\section{3. 水合物破碎、回收与分离一体化钻采技术及} 装备

该技术是基于海洋天然气水合物固态流化开采 方法而提出的具体实施工艺技术, 国外并没有发展 相关配套技术和装备。国内射流破碎喷嘴工具及 工艺图版已成功应用于水合物流化试采, 配套提 高水合物开采效率的井下回收装置还处于室内集 成联调 / 陆地井实验测试阶段。针对射流破碎流 化开采效率低、漏失严重、采后地层修复等问题, 亟需深化水合物破碎、回收一体化钻采技术及装 备研究。

\section{4. 水合物开采实验模拟平台}

我国研制了水合物合成、分解动力学及物性研 究的相关实验测试装置, 初步搭建了水合物固态流 化开采工具管串实验模拟系统、采空区滑塌实验模 拟装置。国外水合物实验装置多是用于合成、分解 及基础物性研究的模拟测试平台。整体来看, 水合 物降压、固态流化和组合开采工艺研究, 工具管串 适用性评价, 储层风险评估模拟分析所需的技术实 验装置还十分匮乏。

\section{5. “三气合采”技术装备}

我国针对水合物产量低、经济效益差的问题, 提出了水合物、自由气、常规天然气 “三气合采” 技术, 以期充分利用开采装备的使用价值、降低开 采经济成本。然而, 针对 “三气合采” 的海底表层、 中深层天然气水合物、深部油气资源一体化开发的 机制和核心技术装备尚未建立, 缺乏“三气合采” 实施的配套技术装备。

综上, 在水合物开采专用技术装备方面, 国内 处于领先水平: 基于降压法的防砂技术装备保障 了两次试采的顺利进行, 基于固态流化法的水合物 破碎、回收与分离一体化钻采技术与装备和水合物 
开采实验模拟平台均为国际首创, 在浅层疏松浅表 层水合物钻进方面率先攻克预造斜导向水平钻进技 术。此外, 我国提出的 “三气合采” 技术思路有望 成为提高水合物产量、尽早实现水合物商业化开采 的重要技术方向。

\section{四、我国海洋天然气水合物开采的发展思路 与建议}

基于海洋天然气水合物试采的发展现状, 目 前水合物开发存在的挑战主要是持续生产难度大 且产量低、水合物开采专用装备缺乏、试采周期 时间短、安全风险尚未显现等。围绕海洋天然气 水合物安全、规模化开发的战略目标, 亟需突破 非成岩水合物开发面临的环境、装备和地质风险 等世界性难题。为此, 海洋天然气水合物开采技 术与装备的未来发展方向是, 从深水油气、水合 物、海底矿产资源开发都亟需的通用关键技术与 装备, 水合物开采亟需的专用关键技术与装备两 方面入手开展攻关研究。

\section{（一）海洋天然气水合物开发技术与装备发展的战 略目标}

国内外海洋天然气水合物开发关键技术和装备 的发展情况对比表明, 我国的射流破碎回收技术装 备、水合物开采模拟实验平台、“三气合采” 创新 方法整体处于国际领先地位; 但深水浅层水合物开 采预斜导向、安全钻进、水下井口、高效防砂、多 相流葲送举升等卡脖子核心装备被国外企业垄断, 设备国产化率偏低, 与国际先进水平相差 5 8 年。 为此, 我国海洋天然气水合物开发技术装备发展的 战略目标为: 2025 年完成水合物试采配套的安全钻 采关键技术装备研发, 2030 年实现水合物规模化稳 定开采, 2035 年建立一套完整的水合物规模化开发 工程技术装备体系（见表 2)。

\section{（二）通用关键技术与装备的发展方向建议}

1. 研发适用于深海海底矿产资源和水合物协同 开发的智能采掘车

制约深海采矿、深海表层非成岩水合物开采的 核心装备是具有海底表层智能行走、路径规划、高
效采掘能力的智能采掘车。该装备的研制及应用对 推进海洋深水矿产资源（金属矿和水合物矿种）开 发、占领深海能源开发的战略制高点、保障海洋强 国战略的实施具有重大意义。建议设立深海海底矿 产资源和水合物协同开发智能采掘装备研发及应用 重点研发计划项目，打破深海资源开发通用核心技 术装备受制于国外的技术瓶颈。

2. 研发我国深水油气和水合物协同开发的双梯 度钻井技术及装备

与深水油气开采类似, 海洋天然气水合物的开 采面临疏松浅表层安全钻进压力窗口窄、井壁稳定 性差、钻井风险大、成本高的难题, 亟需研发具有 自主知识产权的深水油气和水合物协同开发安全钻 进的双梯度钻井技术及装备, 打破国外技术封锁和 垄断, 保障国家的能源战略安全。建议设立科技重 大专项, 开展深水油气和水合物协同开发的安全钻 进双梯度钻井技术及装备工程示范应用。

3. 海洋深水水合物、海底矿产资源开采和深水 油气开发多相流洜送举升及高效分离装置的研发与 应用

深海资源开发的多相流洜送举升装置直接关 系到深水海洋天然气水合物、海底矿产资源开采㬌 输的产能和深水油气开发海底㫤举升双梯度钻井效 果, 而多相流输送的高效分离装置直接关系到回收 水合物浆体和海底矿产资源管输的能耗。为实现安 全、高效、低成本开发, 亟需开展多相流洜送举升 及高效分离通用关键装置的研发与应用, 实现深水 油气、海洋天然气水合物、海底矿产资源的协同开 发并提供通用装备支撑。

\section{（三）专用关键技术与装备的发展方向建议}

1. 开展深水水合物持续开采高效防砂技术及装 备的研发与应用

水合物钻采防砂、控砂技术与装备的研发和应 用直接关系到水合物的长期持续规模化开发和稳产 增效，建议在高效防砂技术及装备的研发与应用方 向设立重点研发计划项目。

2. 研发深水海洋非成岩水合物高效破碎、回收 分离与洜输一体化钻采技术及装备

海洋天然气水合物的固态流化存在一些问题, 如采掘效率低、漏失严重、泵输能耗高, 缺乏海洋 
表 2 海洋天然气水合物开发技术装备发展的战略规划

\begin{tabular}{|c|c|c|c|}
\hline 发展路线 & 2025 年 (总体跟跑, 部分并跑) & 2030 年 (总体并跑, 部分领跑) & 2035 年 (全面领跑) \\
\hline 顶层规划路线 & $\begin{array}{l}\text { 稳定试采与先导示范; 核心装备海 } \\
\text { 试验证 }\end{array}$ & 实施规模化开采 & $\begin{array}{l}\text { 建立规模化开发的工程技术装备 } \\
\text { 体系 }\end{array}$ \\
\hline 具体实施路线 & 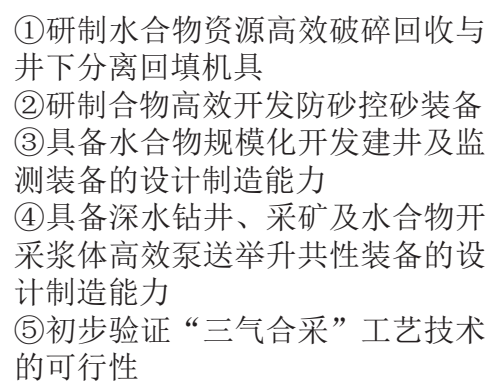 & $\begin{array}{l}\text { 1)建立水合物稳定试采与先导示 } \\
\text { 范配套的高效破碎回收、防砂、 } \\
\text { 井下分离、浆体原送、稳定井口 } \\
\text { 建立及安全监测系统的工程技术 } \\
\text { 装备体系 } \\
\text { (2)试验验证水合物+浅层游离气 } \\
\text { +深部天然气的 “三气合采”工 } \\
\text { 艺可行性 }\end{array}$ & $\begin{array}{l}\text { 形成一套完整的水合物规模化开 } \\
\text { 发工程技术装备体系 }\end{array}$ \\
\hline
\end{tabular}

非成岩水合物高效破碎、回收分离与原输一体化钻 采技术及装备。亟需在水合物流化开采一体化钻采 技术和装备方面获得突破, 推动我国南海海洋天然 气水合物射流破碎回收、泵输、分离回填的一体化 开采模式尽快实现突破。建议在海洋非成岩天然气 水合物高效破碎、回收分离与泵输一体化钻采技术 及装备方向设立重点研发计划项目, 为海洋天然气 水合物规模化开发核心技术装备的工程示范应用提 供支撑。

\section{3. 研发大科学实验装置}

研发大科学实验装置, 为水合物降压、固态 流化和组合开采工艺装备及采掘过程储层风险监 测评估模拟提供实验环境和测试保障。建议设立 重大科研仪器设备研制项目, 为水合物商业化开 采实施的工艺方案设计、配套装备的研发及开采 风险评估提供科学依据和实验平台支撑。

4. 研发 “三气合采” 立体开发工程实施的配套 核心技术及装备

建议在 “三气合采” 立体开发的工程实施方面 设立国家重大科技工程项目, 攻克海洋天然气水合 物稳定试采商业化产气量方面的重大技术瓶颈问 题, 研制 “三气合采” 立体开发实施配套的重大 装备, 促进稳定试采向先导示范过渡。

\section{五、结语}

海洋天然气水合物是一种储量巨大的清洁可替 代能源, 安全、高效、经济地进行开发是当前及未 来一段时间内水合物开采工艺技术及装备的发展目
标。由于仍处于试采技术验证、探索性试采、试验 性试采阶段, 相关技术状态距离水合物实现商业化 开采还有较大差距。今后, 海洋天然气水合物的开 发重在破解海洋非成岩水合物规模化开发时面临 的环境、装备、地质等世界性风险难题方面取得 突破。

海洋天然气水合物开采面临的最主要问题是缺 少一种可保证长期经济、安全的开采方法, 因此后 续研究亟需从战略上探索一种可满足水合物商业化 开采的方法和相关工艺, 既可保证长期开采过程中 不会引发地质环境灾害, 又能兼顾开采量和经济性。 在深化论证新开采方法可行性的基础上, 针对性地 开展具体技术和装备等战术层面的攻关。

为充分利用海洋天然气水合物资源, 建议在国 家层面尽快制定海洋天然气水合物开发技术与装备 的研发计划, 推动水合物的商业化开发进程。尽快 实施海洋非成岩水合物开采专用、通用技术装备的 研发及应用, 带动海洋水合物试采技术进步, 推动 海洋天然气水合物稳定试采与先导示范核心装备的 海试验证; 努力将水合物试采方案和核心技术装备 提升至世界先进水平, 为我国最终实现海洋天然气 水合物的商业化开发, 形成完整的水合物规模化、 商业化开采工程技术装备体系奠定坚实基础。

\section{参考文献}

[1] Sakurai S, Nishioka I, Matsuzawa M, et al. Issues and challenges with controlling large drawdown in the first offshore methane-hydrate production test [J]. SPE Production \& Operations, 2017, 32(4): 500-516.

[2] 张金华, 方念乔, 魏伟, 等. 天然气水合物成藏条件与富集控制 
因素 [J]. 中国石油勘探, 2018, 23(3): 35-46.

Zhang J H, Fang N Q, Wei W, et al. Accumulation conditions and enrichment controlling factors of natural gas hydrate reservoirs [J]. China Petroleum Exploration, 2018, 23(3): 35-46.

[3] Chong Z R, Yang S H B, Babu P, et al. Review of natural gas hydrates as an energy resource: Prospects and challenges [J]. Applied Energy, 2016, 162: 1633-1652.

[4] 吴能友, 黄丽, 胡高伟, 等. 海域天然气水合物开采的地质控制 因素和科学挑战 [J]. 海洋地质与第四纪地质, 2017, 37(5): 1-11. Wu N Y, Huang L, Hu G W, et al. Geological controlling factors and scientific challenges for offshore gas hydrate exploitation [J]. Marine geology and Quaternary Geology, 2017, 37(5): 1-11.

[5] 周守为, 陈伟, 李清平, 等. 深水浅层非成岩天然气水合物固态 流化试采技术研究及进展 [J]. 中国海上油气, 2017, 29(4): 1-8.

Zhou S W, Chen W, Li Q P, et al. Research on the solid fluidization well testing and production for shallow non-diagenetic natural gas hydrate in deep water area [J]. China Offshore Oil and Gas, 2017, 29(4): 1-8.

[6] 张旭辉, 鲁晓兵. 一种新的海洋浅层水合物开采法一一机械-热 联合法 [J]. 力学学报, 2016, 48(5): 1238-1246.

Zhang X H, Lu X B. A new exploitation method for gas hydrate in shallow stratum: Mechanical-thermal method [J]. Chinese Journal of Theoretical and Applied Mechanics, 2016, 48(5): 1238-1246.

[7] 张卫东, 刘永军, 任韶然, 等. 天然气水合物注热开采能量分析 [J]. 天然气工业, 2008 (5): 77-79.

Zhang W D, Liu Y J, Ren S R, et al. Thermal analysis on heat injection to natural gas hydrate $(\mathrm{NGH})$ recovery [J]. Natural Gas Industry, 2008 (5): 77-79.

[8] 李淑霞, 李杰, 曹文. 注热水盐度对水合物开采影响的实验研究 [J]. 高校化学工程学报, 2015, 29(2): 482-486.

Li S X, Li J, Cao W. Experimental studies on the effects of hot brine salinity on gas hydrate production $[\mathrm{J}]$. Journal of Chemical Engineering of Chinese Universities, 2015, 29(2): 482-486.

[9] 张旭辉, 鲁晓兵, 李鹏. 天然气水合物开采方法的研究综述 [J]. 中国科学: 物理学 力学 天文学, 2019, 49(3): 38-59.

Zhang X H, Lu X B, Li P. A comprehensive review in natural gas hydrate recovery methods [J]. SCIENTIA SINICA Physica, Mechanica \& Astronomica, 2019, 49(3): 38-59.

[10] 张学民, 李金平, 吴青柏, 等. $\mathrm{CO}_{2}$ 置换天然气水合物中 $\mathrm{CH}_{4}$ 的研 究进展 [J]. 过程工程学报, 2014, 14(4): 715-720.

Zhang X M, Li J P, Wu Q B, et al. Research progress in replacement of $\mathrm{CH}_{4}$ from methane hydrate with $\mathrm{CO}_{2}[\mathrm{~J}]$. The Chinese Journal of Process Engineering, 2014, 14(4): 715-720.

[11] Ota M, Morohashi K, Abe Y, et al. Replacement of $\mathrm{CH}_{4}$ in the hydrate by use of liquid $\mathrm{CO}_{2}[\mathrm{~J}]$. Energy Conversion and Management, 2005, 46(11-12): 1680-1691.
[12] Sun X, Luo T, Wang L, et al. Numerical simulation of gas recovery from a low-permeability hydrate reservoir by depressurization [J]. Applied Energy, 2019, 250: 7-18.

[13] 吴起, 卢静生, 李栋梁, 等. 降压开采过程中含水合物沉积物的 力学特性研究 [J]. 岩土力学, 2018, 39(12): 4508-4516.

Wu Q, Lu J S, Li D L, et al. Experimental study of mechanical properties of hydrate-bearing sediments during depressurization mining [J]. Rock and Soil Mechanics, 2018, 39(12): 4508-4516.

[14] 周守为, 陈伟, 李清平. 深水浅层天然气水合物固态流化绿色开 采技术 [J]. 中国海上油气, 2014, 26(5): 1-7.

Zhou S W, Chen W, Li Q P. The green solid fluidization development principle of natural gas hydrate stored in shallow layers of deep water [J]. China Offshore Oil and Gas, 2014, 26(5): $1-7$.

[15] Konno Y, Fujii T, Sato A, et al. Key findings of the world's first offshore methane hydrate production test off the coast of Japan: Toward future commercial production [J]. Energy \& Fuels, 2017, 31(3): 2607-2616.

[16] Yamamoto K, Wang X X, Tamaki M, et al. The second offshore production of methane hydrate in the Nankai Trough and gas production behavior from a heterogeneous methane hydrate reservoir [J]. RSC Advances, 2019, 9(45): 25987-26013.

[17] Li J F, Ye J L, Qin X W, et al. The first offshore natural gas hydrate production test in South China Sea [J]. China Geology, 2018, 1(1): 5-16.

[18] 叶建良, 秦绪文, 谢文卫, 等. 中国南海天然气水合物第二次试 采主要进展 [J]. 中国地质, 2020, 47(3): 557-568.

Ye J L, Qin X W, Xie W W, et al. Main progress of the second gas hydrate trial production in the South China Sea [J]. Geology of China, 2020, 47(3): 557-568.

[19] Wei N, Sun W, Meng Y C, et al. Multiphase non equilibrium pipe flow behaviors in the solid fluidization exploitation of marine natural gas hydrate reservoir [J]. Energy Science \& Engineering, 2018, 6(6): 760-782.

[20] Wang L, Wang G, Mao L, et al. Experimental research on the breaking effect of natural gas hydrate sediment for water jet and engineering applications [J]. Journal of Petroleum Science and Engineering, 2020, 184: 1-8.

[21] 王国荣, 钟林, 刘清友, 等. 基于双层管双梯度深海油气及水合 物开发技术研究 [J]. 海洋工程装备与技术, 2019, 6(S1): 225233.

Wang G R, Zhong L, Liu Q Y, et al. Research on marine petroleum and hydrate development technology based on dual gradient drilling of double-layer pipe [J]. Ocean Engineering Equipment and Technology, 2019, 6(S1): 225-233. 